\title{
APLIKASI BIOTEKNOLOGI MOLEKULER DALAM BUDIDAYA PERAIRAN
}

\author{
Oleh \\ Indyaswan Tegar Suryaningtyas ${ }^{1)}$
}

\begin{abstract}
MOLECULAR BIOTECHNOLOGY APPLICATIONS IN MARINE AQUACULTURE. Aquaculture industry, as a promising solution for the decrease of natural brood stock as well as an important part in people's health and economics, has been growing rapidly. Biomolecular technologies are now used as a base for proper management of aquaculture program. Those technologies include breeding program with genetic maps; mono-sex aquaculture program to maximize production's effectiveness; transgenic program; and pathogen's early detection using bio-molecular methods. It can be said that the modern aquaculture industry nowadays depends on the application of molecular biotechnology with supports from better aquaculture-system management for product optimization.
\end{abstract}

\section{PENDAHULUAN}

Budidaya perairan atau akuakultur menjadi bagian penting bagi kehidupan jutaan manusia di dunia sebagai sumber makanan, nutrisi, pendapatan, dan mata pencaharian. Produksi akuakultur global tumbuh dengan cukup pesat, dari semula kurang dari satu juta ton pada tahun 1950-an menjadi hampir 77 juta ton pada tahun 2015 (FAO, 2017). Kecenderungan tingkat konsumsi ikan dunia yang terus meningkat, yang dipicu oleh tingginya kesadaran masyarakat dalam memandang produk perikanan sebagai sumber protein yang sehat dan aman, menjadi salah satu alasan giatnya usaha budidaya. Sebaliknya, menurunnya hasil penangkapan ikan akibat adanya overfishing dan isu-isu lingkungan yang memengaruhi hasil penangkapan, telah menjadi perhatian serius dunia internasional sejak tahun 1980-an. Negara-negara yang sebelumnya hanya fokus memanfaatkan teknologi penangkapan, kini mulai mengubah kebijakan pengelolaan sumberdaya perikanan melalui kegiatan budidaya perairan (Subasinghe et al., 2009).

Teknologi budidaya semakin dikembangkan untuk memperoleh kualitas dan kuantitas produk terbaik dalam memenuhi kebutuhan pasar. Selain fasilitas dan sarana budidaya yang semakin canggih, manajemen budidaya perairan juga semakin diperhatikan (Subasinghe et. al., 2009). Untuk mengatasi ketersediaan biota budidaya berkualitas, pendekatan kajian

\footnotetext{
1) Laboratorium Budidaya Biota Laut, Pusat Penelitian Oseanografi, LIPI
} 
bioteknologi molekuler mulai dilakukan (Penman, 2004). Kehadiran bioteknologi molekuler sebagai salah satu cabang dari ilmu biologi semakin memacu berkembangnya kegiatan budidaya dengan mendasari temuan-temuan berharga yang menjadi jawaban dalam permasalahan yang sebelumnya tidak dapat diselesaikan dengan teknologi tradisional, khususnya di lingkup bidang hayati. Informasi yang berhasil diungkap oleh ilmu ini dapat mendukung langkah-langkah yang tepat dalam usaha budidaya meliputi pemuliaan benih unggul, percepatan kematangan gonad, memperpendek waktu panen, peningkatan resistensi terhadap patogen, pemberian pakan yang sesuai dan efisien serta percobaan manipulasi ekspresi gen yang diinginkan untuk optimalisasi hasil akuakultur dengan lingkungan yang terkontrol (Mair et al., 2007).

\section{INFORMASI GENETIK SEBAGAI} DASAR BIOLOGI MOLEKULER

Perkembangan pesat dalam keilmuan hayati, khususnya di bidang biologi-molekuler, telah mempercepat laju perkembangan bioteknologi. Kajian ilmu ini merujuk pada wilayah kehidupan dalam skala molekuler dengan segala interaksinya yang meliputi
DNA (Deoxyribonucleic acid), RNA (Ribonucleic acid), protein sintesis dan pengaturan serta ekspresi - ekspresinya. Informasi dan karakteristiknya dimanfaatkan menjadi media kajian intensif dalam menjawab permasalahan di bidang hayati (Prescott, 2012).

DNA merupakan asam nukleat yang tergolong biomolekul utama penyusun jaringan organisme yang umumnya terletak di dalam inti sel (Prescott, 2012). DNA sebagai materi genetik yang menyimpan cetak biru (blue print) semua karakter dan aktifitas sel, berperan penting dalam transfer informasi genetik dari satu organisme ke organisme lainnya. Teknologi rekombinan DNA yang disebut juga sebagai kloning gen atau kloning molekuler menjadi landasan utama bagi pengembangan bioteknologi molekuler. Metode yang paling umum digunakan dalam amplifikasi fragmen DNA spesifik adalah metode Polymerase Chain Reaction (PCR) (Gambar 1.) (Erlich, 2015). Hasil amplifikasi fragmen DNA dapat dimanfaatkan untuk penelitian lebih lanjut seperti seleksi gen-gen unggul dalam rangka pemuliaan bibit unggul (McAndrew \& Napier, 2010) atau modifikasi ekspresi gen untuk memperoleh sifat yang diinginkan (Davidson, 2007). 


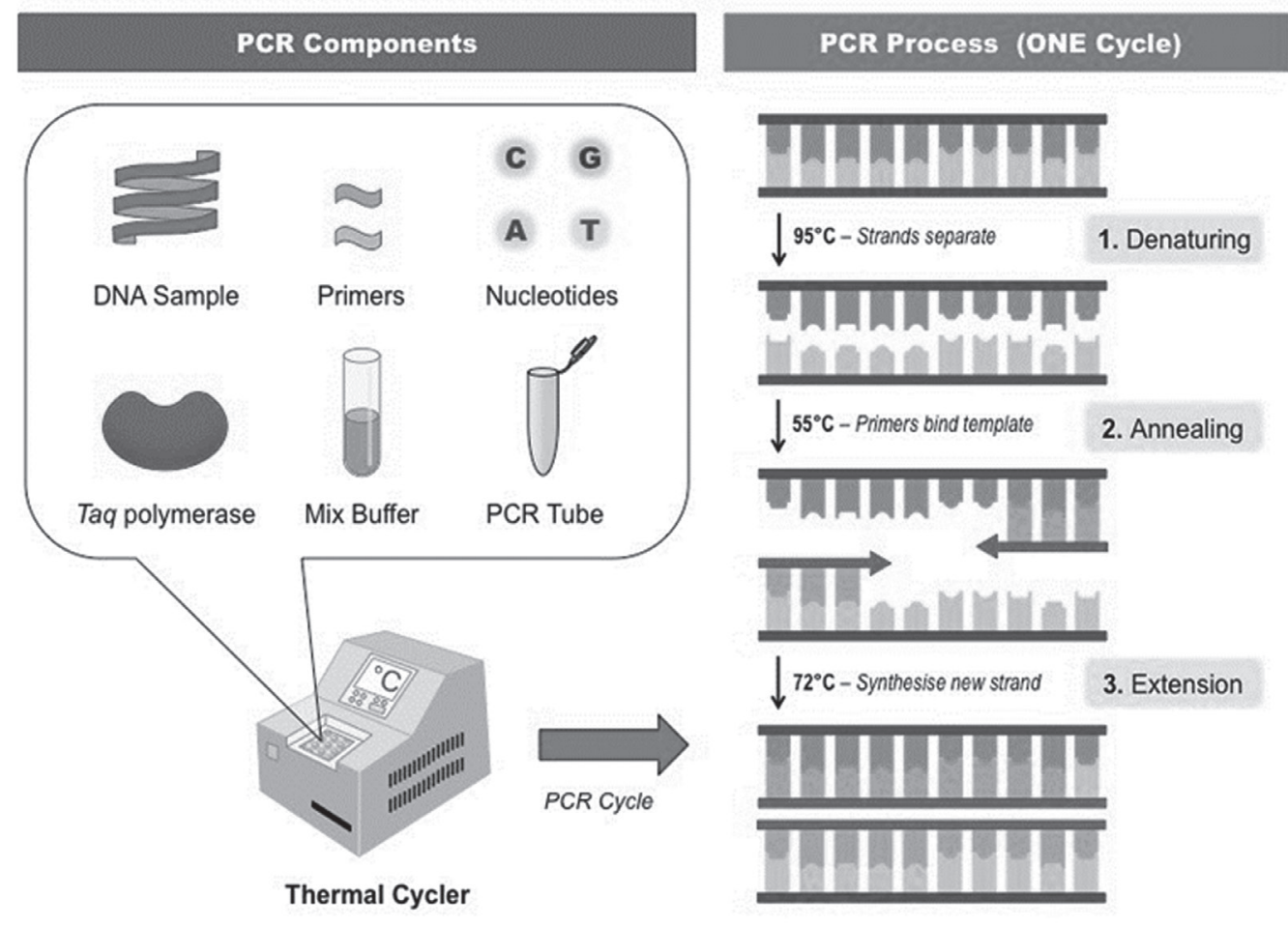

Gambar 1. Metode amplifikasi fragmen DNA menggunakan PCR. Komponen dan proses PCR. http://ib.bioninja.com.au/pcr.html)

\section{BREEDING BERDASARKAN PETA GENETIK}

Usaha-usaha pembenihan dan domestikasi biota budidaya menjadi solusi terhadap ketergantungan benih dari alam yang ketersediaannya semakin berkurang. Namun, permasalahan baru pun muncul ketika penelitian membuktikan bahwa biota hasil pembenihan secara tradisional tanpa adanya percampuran genetik dari biota liar hasil tangkapan menyebabkan penurunan kualitas genetik dari biota tersebut. Apabila dilihat secara global, kurang lebih hanya 5\% dari kegiatan pembenihan yang menggunakan program yang tepat, melalui pemuliaan benih dan penelitian secara ilmiah (Gjedrem, 2005).
Sebagai jawaban dari persoalan tersebut, pendekatan bioteknologi molekuler dengan kajian-kajian biodiversitas genetik menggunakan metode biomolekuler akan mampu memetakan kualitas keragaman genetik suatu organisme. Keragaman genetik yang berhasil dipetakan selanjutnya dapat dimanfaatkan sebagai landasan breeding untuk menghasilkan benih yang unggul. Metode pemetaan genetik dilakukan dengan memanfaatkan perbedaan variasi gen yang spesifik di dalam suatu wilayah untai DNA individu atau yang biasa disebut dengan sidik jari DNA (DNA fingerprint). Sidik jari DNA spesifik memiliki karakteristik pembeda dengan 
sidik jari DNA individu lain (Macbeth, 2005). Beberapa contoh metode teknologi sidik jari DNA untuk pembuatan peta genetik yang sudah dilakukan adalah Restriction Fragment Length Polymorphism (RFLP) (Goodier \& Davidson, 1993), dan Random Amplified Polymorfic DNA (RAPD) (Chauhan \& Rajiv, 2010). Kajian sumberdaya keragaman genetik dapat diidentifikasi dan dijadikan dasar ilmiah bagi upaya pemuliaan, breeding dan reproduksi dalam pengembangan budidaya perairan. Dengan menggunakan metode sidik jari DNA, ikan dapat diidentifikasi perbedaannya hanya dengan beberapa tetes darah atau sedikit sampel sel saja. Selanjutnya persilangan dan keturunan dari persilangan genetik yang berbeda dapat diketahui (Goddard \& Hayes, 2009). Pemetaan gen membantu dalam pelaksanaan studi-studi genetika kuantitatif dalam budidaya perairan.

Tersedianya peta tentang keragaman genetik, breeding dapat dilakukan berdasarkan peta genomik suatu individu, sehingga tidak hanya menggunakan sumber induk dari satu lokasi saja, namun dimungkinkan juga akan terjadi persilangan induk dari sumber yang lain berdasarkan informasi tingkat keragaman genetik masingmasing induk dari lokasi yang berbeda. Manajemen pemilihan induk seperti ini akan memungkinkan terjaganya kualitas dan keragaman genetik suatu sumberdaya hayati di suatu wilayah (Goddard \& Hayes, 2009). Hasil persilangan dari induk dengan kualitas genetik yang bagus akan menghasilkan pula benih dengan kualitas bagus. Karakteristik benih yang dihasilkan dapat direkayasa sesuai keinginan semisal ukuran yang semakin besar, ketahanan terhadap penyakit dan masa panen yang pendek. Bagi industri perikanan dan budidaya, ketersediaan benih yang berkualitas adalah salah satu hal yang menjadi prioritas untuk dipertimbangkan (Chauhan \& Rajiz, 2010). Sedangkan bagi kelestarian sumberdaya, benih yang unggul sangat mendukung upaya restocking terhadap biota yang perlu diperbaiki dengan cepat.

\section{BUDIDAYA SEJENIS (MONOSEX CULTURE)}

Pada beberapa biota, terdapat perbedaan sifat antara individu jantan dan betina yang memengaruhi sifat-sifat yang menguntungkan secara ekonomis, seperti kecepatan pertumbuhan dan ketahanan terhadap penyakit (Chakraborty et al., 2011). Terkait dengan hal tersebut, maka dalam industri budidaya perairan, dikenal adanya budidaya sejenis atau biasa disebut dengan monosex culture yang diketahui lebih menguntungkan daripada budidaya dengan jenis kelamin campur. Beberapa contoh keuntungan monosex culture antara lain adalah ditemukan pada ikan sturgeon betina yang menghasilkan caviar (telur ikan) ; ikan nila jantan yang tumbuh lebih cepat daripada betina, ikan salmon dan trout betina lebih cepat tumbuh daripada ikan jantan; serta kepiting betina tumbuh lebih lambat dan lebih kanibal (Cnaani \& Levavi-Sivan, 2009).

Produksi biota budidaya secara monoseks dapat dilakukan dengan cara manipulasi perkembangan gamet dan 
embrio. Manipulasi dilakukan dalam bentuk denaturalisasi DNA sel kelamin yang dilanjutkan dengan manipulasi bentuk kromosom atau sex reversal menggunakan perlakuan hormon atau perlakuan kimia dan fisika selama proses pembenihan. Penggunaan hormon yang tepat dan terprogram dapat merubah sifat fenotip kelamin ikan. Sebagai contoh, ikan nila jantan akan berubah secara fisik menjadi betina dengan pemberian hormon estrogen. Ikan-ikan jantan "buatan" ini kemudian dikawinkan dengan ikan jantan alami untuk menghasilkan anakan ikan nila yang semuanya berjenis kelamin jantan. Ikan nila jantan diketahui memiliki pertumbuhan yang lebih cepat. Anakan jantan yang dihasilkan dari proses ini memiliki dua kromosom jantan yang dapat digunakan untuk indukan pembenihan selanjutnya (Cnaani \& Levavi-Sivan, 2009). Oleh karena itu, dengan metode ini, semua populasi jantan bisa diproduksi untuk generasi selanjutnya tanpa perlu lagi penambahan hormon. Metode ini juga dapat menghindari perkawinan yang tidak diinginkan yang biasa terjadi pada budidaya ikan nila secara multi-sex. Kasus yang terjadi dalam budidaya ikan nila multi-sex adalah terjadinya perkawinan ikan-ikan berukuran kecil yang menyebabkan kepadatan yang berlebih (Chakraborty et al., 2011).

\section{TEKNOLOGI TRANSGENIK}

Dasar dari teknologi rekayasa genetik adalah transfer gen. Teknologi ini memungkinkan untuk merubah gen-gen pada suatu spesies kepada spesies yang lain, misalnya gen yang mengekspresikan protein antibeku dari ikan laut yang tahan dingin ke ikan lain yang tidak tahan terhadap dingin (Dunham, 2009). Gen anti beku yang ditransfer pada ikan salmon menghasilan ikan salmon yang memiliki toleransi terhadap suhu dingin, dengan harapan dapat memperluas pembudidayaan ikan tersebut. Selain memperluas jangkauan ikan salmon di perairan yang lebih dingin, protein anti beku yang dihasilkan oleh gen baru ini juga memungkinkan salmon untuk berkembang secara normal selama musim dingin (Menozi et al. 2012). Transfer gen pada ikan biasanya dilakukan dengan gen-gen yang menghasilkan hormon pertumbuhan, seperti yang telah dilakukan pada ikan mas, kelompok catfish, salmon, ikan nila, mudloach, dan trout, yang menghasilkan peningkatan kecepatan pertumbuhannya (Dunham, 2009).

Salah satu teknik yang digunakan dalam teknologi transfer gen adalah mikroinjeksi (Gambar 2), yaitu gen yang akan diintroduksi disuntikkan ke sel target menggunakan gelas pipet yang sangat kecil $(0,05-0,15 \mathrm{~mm})$ (Luo et al., 2015). Pada ikan medaka, larutan fragmen DNA yang berisi fragmen gen disuntikkan ke inti telur yang belum matang, pada saat korion masih lembut, karena telur medaka akan menjadi sangat keras setelah dibuahi. Telur tersebut kemudian diinkubasi secara in vitro (Luo et al., 2015). Prosedur ini rumit dan membutuhkan waktu yang relatif lama apabila diaplikasikan pada spesies selain medaka. Solusi yang dilakukan untuk mengatasi permasalahan tersebut adalah dengan cara menyuntikkan gen yang telah diamplifikasi dalam jumlah besar ke 
sitoplasma telur yang telah dibuahi (Luo et al., 2015).

Metode lain yang penting dalam pembuatan biota transgenik adalah menggunakan teknik elektroforesis, yang pada prinsipnya adalah dengan membuat lubang pada membran sel menggunakan bantuan getaran aliran listrik (electric pulse), yang kemudian dapat disisipi fragmen DNA dari suspensi sel-larutan DNA (Gambar 3) (Xu et al., 2011). Metode ini telah berhasil digunakan untuk membuat biota transgenik dari spesies budidaya seperti kelompok ikan catfish, ikan mas dan salmon (Dunham, 2009; Xu et al., 2011).

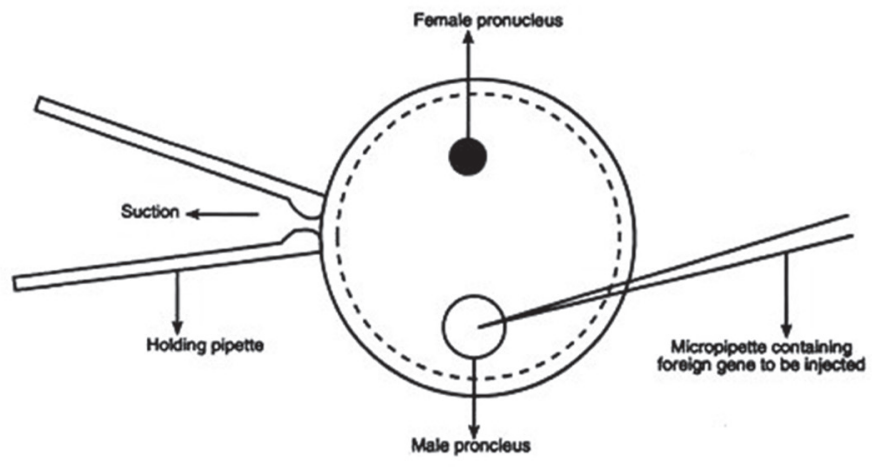

Gambar 2. Metode mikroinjeksi untuk interoduksi gen ke sel target.

(http://www.yourarticlelibrary.com/fish/genetics-fish/transgenic-fishes-meaningdevelopment-and-application/88723/)

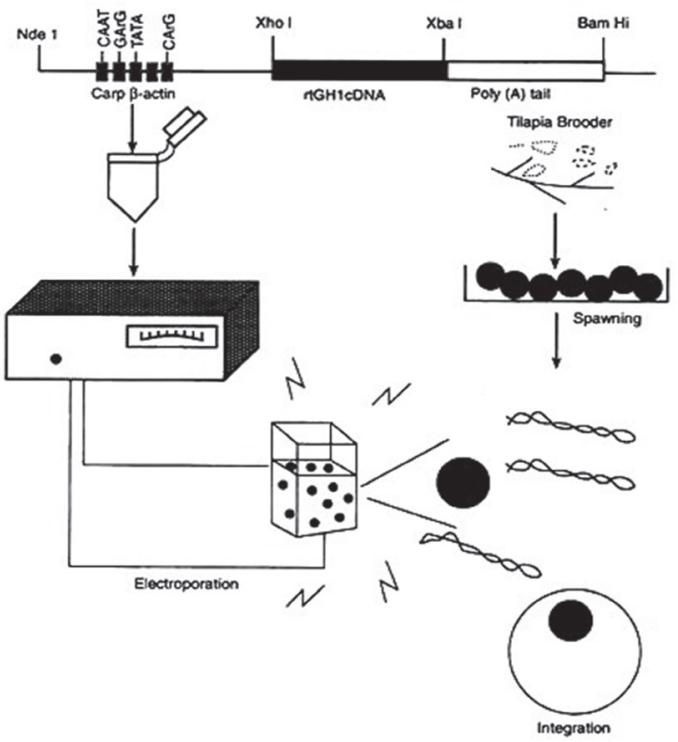

Gambar 3. Teknik transfer gen dengan elektroforesis.

(http://www.yourarticlelibrary.com/fish/genetics-fish/transgenic-fishes-meaningdevelopment-and-application/88723/) 
Aplikasi metode mikroinjeksi dan elektroforesis tidak dapat dilakukan bagi biota yang perkembangan embrionya berada di dalam tubuh induknya, serta biota yang tidak melepaskan telurnya setelah pembuahan, seperti pada krustasea (udang dan lobster) $(\mathrm{Pu}$ et al.,2017). Oleh karena itu, berkembanglah alternatif metode transfer gen yang lain, yaitu replication-defective pantropic retroviral, yaitu metode yang memanfaatkan bantuan dari sebuah vektor sebagai pembawa informasi genetik (Sarmasik et al., 2001). Sarmasik et al. (2001) menyuntikkan vektor yang telah berisi informasi genetik yang ingin diinteroduksi ke daerah sekitar gonad pada ikan gapi (Poecilia lucidai) dan crayfish (Procambarus clarkii). Sedangkan Lu et al. (2002) mengaplikasikan metode ini dengan menyuntikkan cDNA hormon pertumbuhan ikan rainbow trout dengan promoter ikan mas yang dicampurkan dengan liposom ke gonad ikan, dan menghasilkan ikan silver bream transgenik. Keberhasilan transfer gen menggunakan metode tersebut memberikan hasil yang relatif sama dibandingkan dengan metode elektroforesis (Lu et. al. 2002).

\section{IDENTIFIKASI PATOGEN DAN PENCEGAHANNYA}

Patogen merupakan ancaman serius dalam industri budidaya. Sejarah mencatat bahwa peristiwa munculnya bakteri Vibrio spp., secara tak terduga menjadi salah satu bakteri yang menghancurkan budidaya udang. Vibrio spp., teridentifikasi dengan berbagai jenis, mulai dari yang bercahaya, namun tidak patogen, yang bercahaya dan patogen, yang tidak bercahaya tetapi pathogen, sehingga deteksi dini bakteri ini dengan cara kultur mikrobiologi cukup sulit untuk dilakukan (Reham \& Amani, 2012). Perbedaan karakteristik Vibrio spp. yang beraneka ragam tersebut kemungkinan muncul, karena organisme ini mengalami suatu proses transformasi genetik, sehingga memiliki variasi yang sangat tinggi (Jayasree et al., 2006).

Identifikasi dini patogen sangat perlu dilakukan demi memperoleh metode penanganan yang paling sesuai. Saat ini telah dikembangkan metode deteksi patogen secara molekuler penyebab penyakit infeksi pada organisme budidaya baik oleh bakteri maupun virus tanpa proses pembiakan, yaitu dengan metode amplifikasi fragmen DNA dari organisme budidaya dengan menggunakan PCR (Tunung et. al., 2010). Pada dasarnya, material genetik suatu organisme membawa informasi gen yang diekspresikan menjadi senyawa tertentu. Urutan nukleotida yang menghasilkan senyawa biologis tertentu merupakan suatu penanda genetik spesifik yang dapat digunakan sebagai penentu diagnosis patogen. Terkait dengan hal tersebut, maka dengan metode amplifikasi suatu fragmen DNA spesifik untuk penyakit virus dan bakteri dengan bantuan primer spesifik menggunakan PCR, deteksi penyakit dapat dilakukan tanpa perlu melakukan kultur patogen (Ponniah et al., 2010). Metode ini memungkinkan untuk memperoleh hasil identifikasi yang 
lebih akurat, terutama untuk meneliti keberadaan patogen yang memerlukan waktu inkubasi lama, patogen yang tidak dapat diperoleh dalam jumlah yang cukup banyak, dan patogen yang tidak dapat dikultur secara in vitro (Tunung et al., 2010).

\section{Efektifitas penggunaan PCR} sebagai metode deteksi patogen, dapat memacu perkembangan teknologi ini. Salah satu hasil pengembangan teknologi PCR adalah Real Time PCR, yaitu metode deteksi dengan menggunakan target DNA pilihan dengan jumlah duplikasi yang tinggi dalam kromosom. Perbedaan antara teknik ini dengan PCR konvensional adalah dalam penggunaan pelacak berfluorensi yang memungkinkan untuk dapat mengetahui jumlah kuantitatif pathogen yang menginfeksi suatu organisme (Faye et.al, 2013). Penggunaan Real Time PCR juga sangat bermanfaat untuk mengetahui seberapa banyak ekspresi suatu gen, untuk mempelajari aspek fisologi organisme (Lanciotti et.al., 2008).

Selain Real Time PCR, ada pula Speedy PCR yang mampu mengamplifikasi secara paralel pada DNA atau RNA virus menggunakan primer spesifik yang berbeda sesuai jenis infeksi virusnya, namun dengan thermocycle yang sama. Oleh karena itu, dengan teknik tersebut waktu dan biaya deteksi menjadi lebih efisien dibandingkan dengan PCR konvensional.

Berkat penggunaan metode deteksi patogen secaramolekuler, berbagai infeksi patogen baik bakteri maupun virus seperti
Vibrio harveyi, Vibrio alginoliticus, White Spot Syndrome Virus (WSSV), Taura Syndrome Virus (TSV), Infectious MyoNecrosis Virus (IMNV), Infectious Hypodermal dan Hematopoietic Necrosis Virus (IHHNV), Monodon Baculo Virus (MBV), Hepatopancreatitis Bacteria (NHPB) dapat teridentifikasi sejak dini (Gui \& Zhu, 2012).

Serangan bakteri patogen dan virus bukanlah satu-satunya permasalahan penyebab kematian biota budidaya. Selain kualitas air yang menurun karena masuknya bahan organik maupun polutan di dalam sistem budidaya, daya tahan tubuh organisme budidaya adalah hal yang penting untuk diperhatikan. Walaupun suatu sistem budidaya telah tercemar polusi maupun terpapar oleh agen patogen, namun apabila imunitas dan kesehatan organisme budidaya tinggi, kemampuan untuk bertahan hidup pun semakin tinggi. Oleh karena itu, evaluasi mutu kualitas genetik suatu biota budidaya dalam menghasilkan benih dengan daya tahan tubuh yang baik merupakan salah satu tindakan preventif yang tepat untuk mencegah kematian akibat serangan patogen. Mutu kualitas genetik tersebut dapat dievaluasi menggunakan pendekatan bioteknologi molekuler.

\section{PENUTUP}

Perhatian serius dunia internasional terhadap perikanan dan budidaya perairan, ditunjukkan dengan banyaknya dukungan penelitian mengenai teknologi budidaya dari segala aspek. 
Perkembangan pesat ilmu pengetahuan khususnya pada bidang bioteknologimolekuler mendorong perkembangan teknologi budidaya tersebut.

Di masa depan, penelitian dan industri budidaya akan lebih fokus dalam menanggapi isu-isu yang berkaitan dengan biomolekuler seperti pemahaman terhadap regulasi gen dan metode rekayasa agar memperoleh produk yang diinginkan, identifikasi kualitas genetik sumber indukan unggul, identifikasi gen-gen fungsional dan penanda molekulernya, dan penemuanpenemuan teknologi baru yang dapat diaplikasikan dalam pengembangan usaha pembenihan dan pembesaran dengan dasar informasi genetik dalam penentuan program budidaya yang tepat. Strategi dan program budidaya yang tepat akan menghasilkan metode-metode baru dalam menghasilkan produk budidaya dengan varietas berkualitas dan tentunya akan memberikan kontribusi yang besar dalam industri perikanan berkelanjutan dan inovasi bioteknologi.

\section{DAFTAR PUSTAKA}

Chakraborty, S. B., D. Mazumdar, U. Chatterji and S. Banerjee. 2011. Growth of mixed-sex and monosex nile Tilapia in different culture systems. Turkish Journal of Fisheries and Aquatic Sciences 11: 131138.

Chauhan, T. and K. Rajiv. 2010. Molecular markers and their application in fisheries and aquaculture. Advances in Bioscience and Biotechnology 1: 281-291.

Cnaani, A., and B. Lavavi-Sivan. 2009. Sexual development in fish, practical applications for aquaculture. Sexual Development 3:164-175

Davidson, W. S. 2007. Bacterial artificial chromosome libraries and BAC based physical mapping of aquaculture genomes. In Aquaculture Genome Technologies (Ed. Z. J. Liu) :245-259.

Dong C. H., S. T.Yang and Z. A. Yang. 2004. A C-type lectin associated and translocated with cortical granules during oocyte maturation and egg fertilization in fish. Development Biology 265: 341-354.

Dunham, R. A. 2009. Transgenic fish resistant to infectious diseases, their risk and prevention of escape into the environment and future candidate genes for disease transgene manipulation. Comparative Immunology, Microbiology and Infectious Diseases 32: 139-161.

Erlich, H. 2015. PCR technology: Principles and applications for DNA amplification. Springer, Berlin : 264p.

Faye, O., O. Faye, D. Diallo, M. Diallo, M. Weidmann and A. Alpha. 
2013. Quantitative real-time PCR detection of Zika virus and evaluation with field-caught Mosquitoes. Virologi Journal 10:311.

Goddard, M. E. and B. J. Hayes. 2009. Mapping genes for complex traits in domestic animals and their use in breeding programmes. Nature Reviews. Genetics 10 (6): 381-91.

Gjedrem, T. 2005. Selection and breeding programs in aquaculture. Springer, Berlin : 364p.

Goodie, J. L. and W. S. Davidson. 1993. A repetitive element in the genome of Atlantic salmon, Salmo salar. Gene 131: 237242.

Gui, J. F. and Z. Y. Zhu. 2012. Molecular basis and genetic improvement of economically important traits in aquaculture animals. Chinese Science Bulletin. 57 (15): $1751-1760$.

Jayasree, L., P. Janakiram and R. Madhavi. 2006. Characterization of Vibrio spp. associated with diseased shrimp from culture ponds of Andhra Pradesh (India). Journal of The world Aquaculture Society 37(4): 523-532.

Lanciotti R. S, O. L. Kosoy, J. J. Laven, J. O. Velez, A. J. Lambert, A. J Johnson, S. M. Stanfield, and M. R. Duffy. 2008. Genetic and serologic properties of Zika Virus associated with an epidemic, Yap State, Micronesia. Emergency Infectious Disease 14 (8):12321239.

Lu, J., F. Bo-Hua, W. Jen-Leh and T. T. Chen. 2002. Production of transgenic silver sea bream (Sparus sarba) by different gene transfer methods. Marine Biotechnology 4: 328-337.

Luo, D., Y. Liu, J. Chen, X. Xia, M. Cao, B. Cheng, X. Wang, W. Gong, C. Q, Y. Zhang, C. H. K. Cheng, Z. Zhu, and W. Hu. 2015. Direct production of XYDMY - sex reversal female medaka (Oryzias latipes) by embryo microinjection of TALENs. Scientific reports 5: 14057.

Macbeth, M. 2005. Rates of inbreeding using DNA fingerprinting in aquaculture breeding programs at various broodstock fitness levels - a simulation study. Australian Journal of Experimental Agriculture 45(8) 893-900.

Mair, G. C., Y. K. Nam and I. I. Solar. 2007. Risk management: Reducing risk through confinement of transgenic fish. In: A. R. Kapuscinski K. R. Hayes, S. Li and G. Dana (Eds). Environmental risk assessment of genetically modified 
organisms. methodologies for transgenic fish. CABI, Wallingford: 209-238.

McAndrew B. and J. Napier. 2010. Application of genetics and genomics to aquaculture development: current and future directions. Journal of Agriculture Science 149: 143151.

Menozzi, D., C. Mora and A. Merigo. 2012. Genetically modified Salmon for dinner? Transgenic Salmon marketing scenarios. Agriculture Bio Forum 15(3): 276-293.

Penman, D. J. 2004. Aquaculture and fisheries biotechnology: genetic approaches. Journal of Fish Diseases 27: 677.

Prescott, D. M. 2012. Cell Biology A Comprehensive Treatise V3. Gene Expression: The Production of RNA's. Elsevier, Amsterdam: 698p.

$\mathrm{Pu}, \mathrm{L}$., J. Wang, X. Zhang, and $\mathrm{H}$. G. 2017. Development of pseudotyped retroviral system for effective gene transfer and expression in penaeid shrimp cells. Aquaculture 467: 198210.

Reham A. A. and M. S. Amani. 2012. Specific detection of pathogenic Vibrio species in shellfish by using multiplex polymerase chain reaction. Global
Veterinaria, 8 (5): 525-531.

Sarmasik, A., I. K. Jang, C. Z. Chun, J. K. Lu, and T. T. Chen. 2001. Transgenic live-bearing fish and crustaceans produced by transforming immature gonads with replication-defective pantropic retroviral vectors. Marine Biotechnology 3: 470477.

Subasinghe, R., D. Soto and J. Jia. 2009. Global aquaculture and its role in sustainable development. Reviews in Aquaculture 1 (1): 2-9.

Sun M., Z. Li and J. F. Gui. 2010. Dynamic distribution of spindling in nucleoli, nucleoplasm and spindle from primary oocytes to mature eggs and its critical function for oocyte-to-embryo transition in gibel carp. Journal of Experimental Zoology 313A: 461-473.

Tunung R., S. P. Margaret, P. Jeyaletchumi, L. C. Chai, T. C. Zainazor, F. M. Ghazali, Y. Nakaghuchi, M. Nishibuchi and R. Son. 2010. Prevalence and quantification of Vibrio in raw salad vegetables at retail level. Journal of Microbiology and Biotechnology 20 (2): 391396.

Wu N., H. M. Yue and B. Chen. 2009. Histone H2A has a novel variant in fish oocytes. Biology of Reproduction 81: 275-283. 
Xu H. Y, J. F. Gui and Y. H. Hong. 2005. Differential expression of vasa RNA and protein during spermatogenesis and oogenesis in the gibel carp (Carassius auratus gibelio), a bisexually and gynogenetically reproducing vertebrate. Development Dynamics 233: 872-882.

Xu, J., W. Huang, C. Zhong, D. Luo, S. Li, Z. Zhu and W. Hu. 2011. Defining global gene expression changes of the hypothalamicpituitary-gonadal axis in female sGnRH antisense transgenic common carp (Cyprinus carpio). Plos-one 6(6): 1-12. published global aquaculture statistics (online). http:// www.fao.org/ 3/a-bs235e. pdf. Diakses pada tanggal 22 Agustus 2017.

Zhou, X. 2017. An overview of recently 